\title{
Features of Protein-Peptide and Carbohydrate Composition of Supernatants From Tenebrio Molitor Larvae After Cold Acclimation
}

Реферат: В работе хроматографическим методом исследовали молекулярно-массовое распределение белков и пептидов из супернатантов, полученных из личинок Tenebrio molitor после холодовой акклимации. Наибольшее количество пептидных фрракций имеют супернатанты из неакклимированных к холоду личинок T. molitor. Показано, что холодоакклимированные личинки T. molitor содержат низкомолекулярные пептидные фракции с м. м. $(540 \pm 20)-(2255 \pm 85)$ Да, а неакклимированные значительное количество высокомолекулярных пептидов с м. м. (4675 \pm 225$)-(6595 \pm 550)$ Да. Определено содержание сахаров и сахароспиртов в супернатантах акклимированных к холоду и неакклимированных личинок T. тоlitor. Установлено, что концентрация глюкозы у неакклимированных особей T. molitor в 1,34 раза выше, чем у холодоакклимированных. Акклимированные личинки T. molitor содержали большее количество гидрофильных и меньшее количество гидрофобных белков по сравнению с неакклимированными. Также обнаружено, что неакклимированные личинки T. molitor coдержали низкие концентрации сахароспиртов (сорбитола и маннитола), которые отсутствовали у акклимированных.

Ключевые слова: Tenebrio molitor, холодовая акклимация, хроматография, пептиды, сахара, сахароспирты.

Реферат: У роботі хроматографічним методом досліджували молекулярно-масовий розподіл білків і пептидів із супернатантів, отриманих із личинок Tenebrio molitor після холодової аклімації. Найбільшу кількість пептидних фракцій мають супернатанти із неаклімованих до холоду личинок T. molitor. Показано, що холодоаклімовані личинки T. molitor містять низькомолекулярні пептидні фракції з м. м. $(540 \pm 20)-(2255 \pm 85)$ Да, а неаклімовані - значну кількість високомолекулярних пептидів з м. м. (4675 \pm 225$)-(6595 \pm 550)$ Да. Визначено вміст цукру та цукроспиртів у супернатантах аклімованих до холоду та неаклімованих личинок T. molitor. Встановлено, що концентрація глюкози у неаклімованих личинок T. molitor була в 1,34 рази вище, ніж у холодоаклімованих. Аклімовані личинки T. molitor мали більшу кількість гідрофрільних і меншу кількість гідрофобних білків у порівнянні з неаклімованими. Також виявлено, що неаклімовані личинки T. molitor мали низькі концентрації цукроспиртів (сорбітолу та манітолу), які були відсутні у аклімованих.

Ключові слова: Tenebrio molitor, холодова аклімація, хроматографія, пептиди, цукри, цукроспирти.

Abstract: The paper describes the chromatographic studies on the molecular-mass distribution of proteins and peptides of supernatants, derived from Tenebrio molitor larvae during cold acclimation. Supernatants of non-acclimated larvae of $T$. molitor had the highest amount of peptide fractions. It has been shown that cold-acclimated $T$. molitor larvae comprised the low-molecular peptide fractions with MW of $(540 \pm 20)-(2.255 \pm 85) \mathrm{Da}$, and high-molecular peptides with MW of $(4.675 \pm 225)-(6.595 \pm 550)$ Da were characteristic for non-acclimated larvae. The content of sugars and polyols in supernatants of cold-acclimated and non-acclimated T. molitor larvae was determined. It has been found that glucose concentration in non-acclimated T. molitor larvae was in 1.34 times higher than in cold-acclimated ones. Acclimated T. molitor larvae had more hydrophilic and less hydrophobic proteins as compared to non-acclimated ones. As well it has been established that non-acclimated T. molitor larvae had low concentrations of polyols (sorbitol and mannite), which were absent in acclimated insects.

Key words: Tenebrio molitor, cold acclimation, chromatography, peptides, sugars, sugar alcohols.

Многие холодоустойчивые организмы (арктическая и антарктическая рыба $[7,11,19,21]$, насекомые $[4,5,8,9,13,14,17,18]$ и бактерии $[12,20])$ способны адаптироваться к низким температурам благодаря температурно-компенсаторным процессам на разных уровнях биологической организации. Так, на молекулярном уровне у холодоустойчивых организмов синтезируются и аккумулируются

Отдел холодовой адаптации, Институт проблем криобиологии и криомедицины НАН Украины, г. Харьков

\footnotetext{
*Автор, которому необходимо направлять корреспонденцию: ул. Переяславская, 23, г. Харьков, Украина 61016; тел.: (+38 057) 373-74-35, факс: (+38 057) 373-59-52, электронная почта: profgulevskyy@gmail.com

Поступила 06.09.2016

Принята в печать 18.10.2016
}

Many of cold-resistant organisms (Arctic and Antarctic fishes $[5,9,18,21]$, insects $[1,3,6,7,11,12$, $16,17]$ and bacteria $[10,20]$ are adaptable to low temperatures due to the temperature-compensatory processes at various levels of biological organization. For example, at molecular level in cold-resistant organisms the specific proteins (antifreeze proteins and glycoproteins, cold shock proteins), peptides, low mole-

Department of Cold Adaptation, Institute for Problems of Cryobiology and Cryomedicine of the National Academy of Sciences of Ukraine, Kharkiv, Ukraine

\footnotetext{
*To whom correspondence should be addressed:

23, Pereyaslavskaya str., Kharkiv, Ukraine 61016; tel.:+380 57 3737435, fax: +380 57373 5952, e-mail: profgulevskyy@gmail.com
}

Received September, 06, 2016 Accepted October, 18, 2016 
специфические белки (антифризные белки и гликопротеины, белки холодового шока), пептиды, низкомолекулярные криозащитные вещества (сахара, полиолы), а также происходят структурные перестройки некоторых протеинов, в результате которых повышается гибкость [6] и стабильность белковых молекул $[10,15]$, снижается их гидрофобность [16]. Именно биохимические модификации, наблюдаемые вследствие изменения температурных условий среды, способствуют сохранению и оптимизации функций протеинов, что обеспечивает выживание биологического вида. Процесс адаптации живых организмов к низким температурам преимущественно связан со структурными изменениями белков, а также с качественными модификациями спектра белков и углеводов, поэтому представляло интерес установить особенности адаптации холодоустойчивых личинок Tenebrio molitor к низким температурам.

Цель работы - изучить с помощью гель-проникающей и прямофазной высокоэффективной жидкостной хроматографии пептидный и углеводный состав супернатантов, полученных из личинок T. molitor, а также исследовать с помощью обращенно-фазовой хроматографии распределение белков по степени их гидрофобности после холодовой акклимации личинок T. molitor.

\section{Материалы и методы}

В работе использовали личинок $(n=6)$ большого мучного хрущака $T$. molitor последних возрастов, которых содержали при $25^{\circ} \mathrm{C}$ в прозрачных контейнерах, заполненных пшеничными и овсяными отрубями. Перед началом эксперимента насекомых акклимировали при $5 . .7^{\circ} \mathrm{C}$ в течение трех недель. Для получения белков и пептидов личинок T. molitor гомогенизировали в $0,6 \%$-м растворе хлорида натрия на 0,1 M Na-фосфатном буфере $(\mathrm{pH} 7,4)$ с добавлением ингибитора протеаз фенилметилсульфонилфторида («Sigma», США) из расчета шесть особей на 2 мл буфера. Гомогенат центрифугировали 10 мин при $1800 \mathrm{~g}$, затем в течение 60 мин надосадочную жидкость центрифугировали при $100000 \mathrm{~g}$. В исследованиях использовали супернатант.

Количество белка в пробах определяли по методу Бредфорда [3].

Количественную и качественную оценку пептидного состава супернатантов из личинок T. molitor проводили с помощью гель-проникающей хроматографии [1] на колонке размером $400 \times 16$ мм, заполненной поливиниловым гелем «TSK-Gel Toyopearl HW-40 Fine» («Toyo Soda Manufacturing Cо», Япония), применение которого позволяет разделять полипептидные молекулы с м. м. 100-12 000 Да. Через петлевой инжектор в колонку вводили пробы cular weight cryoprotectants (sugars, polyols) are synthesized and accumulated, as well there are structural reorganization of some proteins, resulting in an increased flexibility [4] and stability of protein molecules [8, 14] and decrease in their hydrophobicity [15]. The very biochemical modifications observed due to the changes in environment temperature conditions, promote the maintenance and optimization of protein functions, providing species survival. Adaptation of living organisms to low temperatures is mostly associated with the structural changes in proteins as well as with qualitative modifications of protein and carbohydrate spectrum, therefore it was of interest to establish the cold-adaptation features of Tenebrio molitor larvae to low temperatures.

The research aim was to study peptide and carbohydrate composition of supernatants derived from T. molitor larvae by gel-permeation and high performance liquid chromatography, as well as to investigate the protein distribution on their hydrophobicity extent after cold acclimation of $T$. molitor larvae by reverse phase chromatography.

\section{Materials and methods}

The research was performed in the larvae $(n=6)$ of T. molitor mealworm of last ages, kept at $25^{\circ} \mathrm{C}$ in transparent containers filled with wheat and oat bran. Before the experiment the insects were acclimated at $5 \ldots 7^{\circ} \mathrm{C}$ for three weeks. To derive the proteins and peptides, the larvae were homogenized in $0.6 \% \mathrm{NaCl}$ in 0.1 M Na-phosphate buffer ( $\mathrm{pH} 7.4$ ) supplemented with protease inhibitor phenylmethylsulfonyl fluoride (Sigma, USA) putting six insects per $2 \mathrm{ml}$ of buffer. The homogenate was centrifuged for $10 \mathrm{~min}$ at $1,800 \mathrm{~g}$ then the supernatant was centrifuged for $60 \mathrm{~min}$ at $100,000 \mathrm{~g}$. The supernatant was then used for studies.

Protein concentration in the samples was determined by the Bradford method [19].

Peptide composition of supernatants of T. molitor larvae was quantitatively and qualitatively analyzed using the gel-permeation chromatography in the $400 \times 16 \mathrm{~mm}$ column filled with polyvinyl gel TSK-Gel Toyopearl HW-40 Fine (Toyo Soda Manufacturing Co, Japan), the use of which allows to separate polypeptide molecules with MW 100-12,000 Da.

The samples of $0.2 \mathrm{ml}$ were injected through a loop injector into the column and eluting phosphate buffered saline (18 mM Na $2 \mathrm{mPO}_{4}, 12 \mathrm{mM} \mathrm{NaH} \mathrm{PO}_{4}, 100 \mathrm{mM}$ $\mathrm{NaCl}(\mathrm{pH} 7,4))$ was delivered using a Microperpex LKB 2132 peristaltic pump (LKB, Sweden). Eluent flow rate was $1.63 \mathrm{ml} / \mathrm{min}$. The obtained fractions of low molecular weight peptide compounds were recorded with UV/optical monitor Uvicord SII LKB 2238 (LKB) at $280 \mathrm{~nm}$ wavelength. Monitor signal was collected by Recorder LKB 2210 two-channel potentiometer (LKB) in terms of chromatograms and was supplied to an integrator Waters 746 Data Module (Waters 
объемом 0,2 мл и с помощью перистальтического насоса «Microperpex LKB 2132» («LKB», Швеция) подавали элюирующий фосфатно-солевой буферный раствор (18 мМ Na $\mathrm{HPO}_{4}, 12$ мМ NaH $\mathrm{PO}_{4}$, $100 \mathrm{MM} \mathrm{NaCl}(\mathrm{pH} 7,4))$. Скорость потока элюента составляла 1,63 мл/мин. Полученные фракции низкомолекулярных веществ пептидной природы регистрировали с помощью ультрафиолетового оптического монитора «Uvicord SII LKB 2238» («LKB») при длине волны 280 нм. Сигнал монитора регистрировался двухканальным самопишущим потенциометром «Recorder LKB 2210» («LKB») в виде хроматограмм и подавался на интегратор «Waters 746 Data Module» («Waters Millipore», США) для определения времени удерживания фракции и площади под пиком. В качестве маркеров молекулярных масс использовали рибофлавин с м. м. 376,40 Да, ангиотензин II с м. м. 1046,18 Да, цианокобаламин с м. м. 1355,37 Да, мелитин с м. м. 2846,46 Да, инсулин человека с м. м. 5807,57 Да (все вещества производства «Sigma»).

Аликвоты, взятые из супернатантов, пропускали через мембранные фильтры «Chromafil GF/PET45/25 ZF-S» («Macherey-Nagel», Германия), затем идентифицировали и определяли при $75^{\circ} \mathrm{C}$ содержание сахаров и сахароспиртов методом высокоэффективной прямофазной жидкостной хроматографии с использованием хроматографа «Smartline» («Knauen», Германия) на колонке «Erokat H» («Knauer») размером $300 \times 8$ мм, заполненной поперечно сшитыми сополимерами полистирола с размером пор 10 мкм.

В колонку вводили пробу объемом 0,015 мл. В качестве подвижной фазы использовали воду первой степени очистки со скоростью потока 0,5 мл/мин. Содержание сахаров в супернатантах определяли с помощью рефрактометрического детектора «RI Detector 2300» («Knauer»). Для обработки и вычисления результатов применяли программное обеспечение «Clarity Chrom» («Knauer»). В качестве стандартов использовали глюкозу, сахарозу, фруктозу, лактозу, сорбитол, маннитол (все вещества производства «Sigma»).

Для исследования гидрофобности белков из личинок T. molitor методом обращенно-фазовой высокоэффективной жидкостной хроматографии использовали жидкостный хроматограф «Shimadzu LC-2010» («Shimadzu», Япония) и колонку размером $250 \times 4,6$ мм «Vydac C4» («The Separations Group», США), заполненную сферическим силикагелем с размером пор $300 \AA$.

Белки градиентно элюировали из колонки двумя подвижными фазами (ПФ) реактивов фирмы «Fluka Chemie» (Швейцария) (ПФ А - 90\% буферного раствора с $\mathrm{pH} 4,2,10 \%$ ацетонитрила и ПФ Б$10 \%$ буферного раствора с $\mathrm{pH} 4,2,90 \%$ ацетонитрила) по следующей программе: первые 8 мин
Millipore, USA) to determine the retention time of fraction and the area under the peak. Riboflavin with MW 376.40 Da, angiotensin II with MW 1046.18 Da, cyanocobalamin with MW 1,355.37 Da, melittin with MW 2,846.46 Da, human insulin with MW 5,807.57 $\mathrm{Da}$ (all the substances were of Sigma production) were used as the molecular weight markers.

Aliquots derived from the supernatants were passed through membrane filters Chromafil GF/PET-45/25 ZF-S (Macherey-Nagel, Germany), and then the content of sugars and sugar alcohols were examined and revealed at $75^{\circ} \mathrm{C}$ by high performance liquid chromatography using Smartline chromatograph (Knauer, Germany) in the $300 \times 8 \mathrm{~mm}$ column Erokat H (Knauer) filled with cross-linked polystyrene copolymers with a pore size of $10 \mu \mathrm{m}$.

The sample of $0.015 \mathrm{ml}$ was introduced into the column. Water of the first purification degree with $0.5 \mathrm{ml} / \mathrm{min}$ flow rate was used as mobile phase. Content of sugars in supernatants was determined by RI Detector 2,300 refractometric detector (Knauer). To process and calculate the results the Clarity Chrom software (Knauer) was applied. There were used glucose, sucrose, fructose, lactose, sorbitol, mannite (all substances of Sigma production) as standards.

To investigate $T$. molitor larvae protein hydrophobicity by reverse phase high performance liquid chromatography we have used a liquid chromatograph Shimadzu LC-2010 (Shimadzu, Japan) and the $250 \times 4.6 \mathrm{~mm}$ column Vydac C4 (The Separations Group, USA) filled with spherical silica gel having a pore size of $300 \AA$.

Proteins were gradient eluted from the column with two mobile phases (MP) reagents of Fluka Chemie (Switzerland) (MP A - 90\% of buffer solution at $\mathrm{pH}$ $4.2,10 \%$ of acetonitrile and MP B $-10 \%$ of buffer solution at $\mathrm{pH} 4.2,90 \%$ of acetonitrile) according to the following program: first 8 mins elution was performed with buffer A; from 9 to 35 mins buffer B amount was increased from 0 to $80 \%$; from 36 to $40 \mathrm{~min}$, the concentration of buffer B was not changed.

To prepare buffer solution we have used $0.026 \mathrm{M}$ lithium dihydrogenphosphate solution, which was brought to concentrated phosphoric acid to $\mathrm{pH} 4.2$. Mobile phase flow rate made $0.75 \mathrm{ml} / \mathrm{min}$, column temperature was $30^{\circ} \mathrm{C}$.

Proteins were identified at $280 \mathrm{~nm}$ wavelength with a UV detector SPD-M6A (Shimadzu).

The experimental data were statistically processed using the non-parametric Mann-Whitney criterion. The differences between the samples were considered as significant at $p<0.05$.

\section{Results and discussion}

The study of molecular mechanisms, adaptation of biological objects under conditions of temperature 
элюирование проводили буфером А; с 9 до 35 мин количество буфера Б увеличивали с 0 до $80 \%$; с 36 до 40 мин концентрацию буфера Б не изменяли.

Для приготовления буферного раствора использовали 0,026 М раствор лития дигидрофосфата, который доводили концентрированной фосфорной кислотой до $\mathrm{pH} 4,2$. Скорость потока подвижной фазы составляла 0,75 мл/мин, температура колонки $30^{\circ} \mathrm{C}$.

Идентификацию белков проводили при длине волны 280 нм с использованием УФ-детектора «SPD-M6A» («Shimadzu»).

Статистическую обработку экспериментальных данных выполняли, используя непараметрический критерий Манна-Уитни. Различия между выборками считали значимыми при $p<0,05$.

\section{Результаты и обсуждение}

Актуальная задача современной криобиологии изучение молекулярных механизмов адаптации биообъектов в условиях изменения температурного режима. Процессы, происходящие на молекулярном уровне организации при низкотемпературной адаптации, являются ключевыми для выживания и сохранения биологического вида.

Адаптация живых организмов к низким температурам - сложный и многоэтапный процесс, при котором наблюдаются изменения спектра белков, структурные перестройки некоторых белковых молекул, а также качественные и количественные модификации криозащитных веществ, сахаров и полиолов. В этой связи представлялось интересным изучить особенности адаптации холодоустойчивого биологического вида к действию низких температур.

Согласно данным литературы удобной моделью для исследования молекулярных механизмов холодоустойчивости живых организмов являются личинки большого мучного хрущака T. molitor (семейство: Tenebrionidae), которые, как нами было показано с помощью SDS-электрофореза в ПААГ [2], способны при двухнедельной холодовой акклимации продуцировать белки с м. м. 5-10, 30 и 65 кДа. Также были изучены антифризные белки $[5,14,17,18]$, обеспечивающие переохлаждение личинок $T$. molitor в условиях действия низких температур. Однако изменения всего спектра водорастворимых белков и пептидов, их структурные особенности, а также качественный и количественный состав сахаров и полиолов при холодовой акклимации изучены недостаточно.

С помощью гель-проникающей хроматографии мы получили молекулярно-массовые распределения белково-пептидных веществ из супернатантов, выделенных из акклимированных к холоду и неакклимированных личинок T. molitor (табл. 1, changes is an actual task of current cryobiology. The processes occurring at the molecular level during low temperature adaptation are a key in understanding of survival and conservation of species.

Adaptation of living organisms to low temperatures is complex and multi-step process, accompanied with the changes in protein spectrum, structural rearrangements in molecules of some proteins, as well as qualitative and quantitative modifications of cryoprotectants, sugars and polyols. Therefore, it is of interest to study the adaptation features of cold-resistant species to low temperatures.

As reported widely the mealworm $T$. molitor larvae (Tenebrionidae family) is a convenient model to investigate molecular mechanisms of cold resistance of living organisms. As we have earlier shown using SDS-PAGE electrophoresis [13] they were capable to produce the proteins with MW of 5-10, 30 and $65 \mathrm{kDa}$ during two weeks of cold acclimation. Antifreeze proteins [3, 12, $16,17]$ providing hypothermia of $T$. molitor larvae under low temperature conditions wre also studied. Nevertheless, the information about the changes of the whole spectrum of watersoluble pro-teins and peptides, their structural features, as well as qualitative and quantitative composition of sugars and polyols during cold acclimation are not comprehesive yet.

Using gel-permeation chromatography, we obtained molecular weight distributions of proteins and peptides from supernatants derived from cold-acclimated and non-acclimated T. molitor larvae (Fig. 1, Table 1). Substances with $\mathrm{MW} \leq 7,000$ Da were defined as peptides and substances with $\mathrm{MW} \geq 12,000 \mathrm{Da}$ were considered as proteins.

Analysis of the experimental data presented in Fig. 1, showed that qualitative composition of low-molecular substances of protein-peptide nature from $T$. molitor larvae during cold acclimation was significantly changed. A decrease in peptide fractions number was observed in T. mollitor larvae acclimated for three weeks. A high molecular weight fraction of proteins with $\mathrm{MW} \geq 12,000 \mathrm{Da}$ and low molecular weight fractions with MW $(2.255 \pm 85),(1.525 \pm 115),(1.105 \pm$ $115),(825 \pm 55)$ and $(540 \pm 20)$ Da were the main protein-peptide fractions of supernatants derived from cold-acclimated and non-acclimated $T$. molitor larvae.

Figure 1 shows that supernatants derived from cold acclimated T. molitor larvae contain six low molecular weight peptide fractions with $\mathrm{MW}(540 \pm 20)-$ (2.255 \pm 85$)$ Da. It should be noted that cold acclimation $T$. molitor larvae resulted in disapperance of four high-molecular peptide fractions with MW (6.595 \pm $550),(6.040 \pm 280),(5.325 \pm 195)$ and $(4.675 \pm 225) \mathrm{Da}$ and apperance of low-molecular peptides with $\mathrm{MW}$ $(1.295 \pm 75) \mathrm{Da}$.

Moreover it should be noted that compositions of protein and peptide substances in supernatants, derived 
рис. 1). Вещества с м. м. $\leq 7000$ Да идентифицировали как пептиды, а вещества с м. м. $\geq 12000$ Да - как белки.

Анализ экспериментальных данных, представленных в табл. 1 и на рис. 1, показал, что качественный состав низкомолекулярных веществ белково-пептидной природы из личинок T. molitor в процессе холодовой акклимации существенно изменяется. У акклимированных при $5 . .7^{\circ} \mathrm{C}$ в течение трех недель личинок T. molitor отмечается уменьшение количества пептидных фракций. Основными белковопептидными фракциями из супернатантов, полученных из холодоакклимированных и неакклимированных личинок T. molitor, являются высокомолекулярная фракция белков с м. м. $\geq 12000$ Да и низкомолекулярные пептидные фракции с м. м. (2255 \pm 85$)$, $(1525 \pm 115),(1105 \pm 115)$, $(825 \pm 55)$ и $(540 \pm 20)$ Да.

Как видно из рис. 1, в супернатантах, выделен-ных из акклимированных к холоду личинок T. molitor, присутствуют шесть низкомолекулярных пептидных фракций с м.м. $(540 \pm 20)-(2255 \pm 85)$ Да. Следует отметить, что после акклимации к холоду у личинок T. molitor исчезают четыре высокомолекулярные пептидные фракции с м. м. (6595 \pm 550$),(6040 \pm 280),(5325 \pm$ $195)$ и $(4675 \pm 225)$ Да и появляются низкомолекулярные пептиды с м. м. (1295 \pm 75$)$ Да.

Установлено, что состав белково-пептидных веществ в супернатантах, полученных из акклимированных к холоду и неакклимированных личинок T. molitor, имеет количественные различия. В частности, статистически значимые изменения наблюдаются во фракциях с м. м. (2255 \pm 85$)$, $(1525 \pm 115)$ и $(1105 \pm 115)$ Да, которые соответствуют пикам хроматограмм $\mathrm{A}_{4.2}, \mathrm{~B}_{1}$ и C (рис. 2). В процессе холодовой акклимации личинок T. molitor отмечается уменьшение количества пептидов с м. м. $(2255 \pm 85)$ и $(1525 \pm 115)$ Да в 8 и 2,3 раза соответственно (пики $\mathrm{A}_{4.2}$ и $\mathrm{B}_{1}$ ).

Сравнение хроматограмм распределения белково-пептидных фракций супернатантов, выделенных из акклимированных и неакклимированных к холоду личинок T. molitor, показало, что общее from cold-acclimated and non-acclimated T. molitor larvae, have quantitative differences. In particular, the statistically significant changes were observed in the fractions with MW (2.255 \pm 85$),(1.525 \pm 115)$ and $(1.105 \pm 115) \mathrm{Da}$ corresponding to $\mathrm{A}_{4.2}, \mathrm{~B}_{1}$, and $\mathrm{C}$ chromatogram peaks (Fig. 2). During cold acclimation of $T$. molitor larvae a decrease was observed in the number of peptides with MW (2.255 \pm 85$)$ and (1.525 \pm $115)$ Da by 8 and 2.3 times, respectively $\left(A_{4.2}\right.$ and $B_{1}$ peaks).

Comparing the chromatograms of protein-peptide fractions distribution for supernatants derived from acclimated and non-acclimated $T$. molitor larvae, we have revealed that the total contents of all the components slightly differed. In particular, the content of substances absorbing in UV region of spectrum in coldacclimated insects was by 1.11 times higher than in non-acclimated ones.

During acclimation the distribution of protein and peptide components significantly changed. A comparative analysis of chromatographic data of protein-peptide fractions from $T$. molitor larvae showed that the number of protein fraction ( $P r$ peak) with $\mathrm{MW} \geq 12,000 \mathrm{Da}$ in non-acclimated larvae was in 2.3 times lower than in 

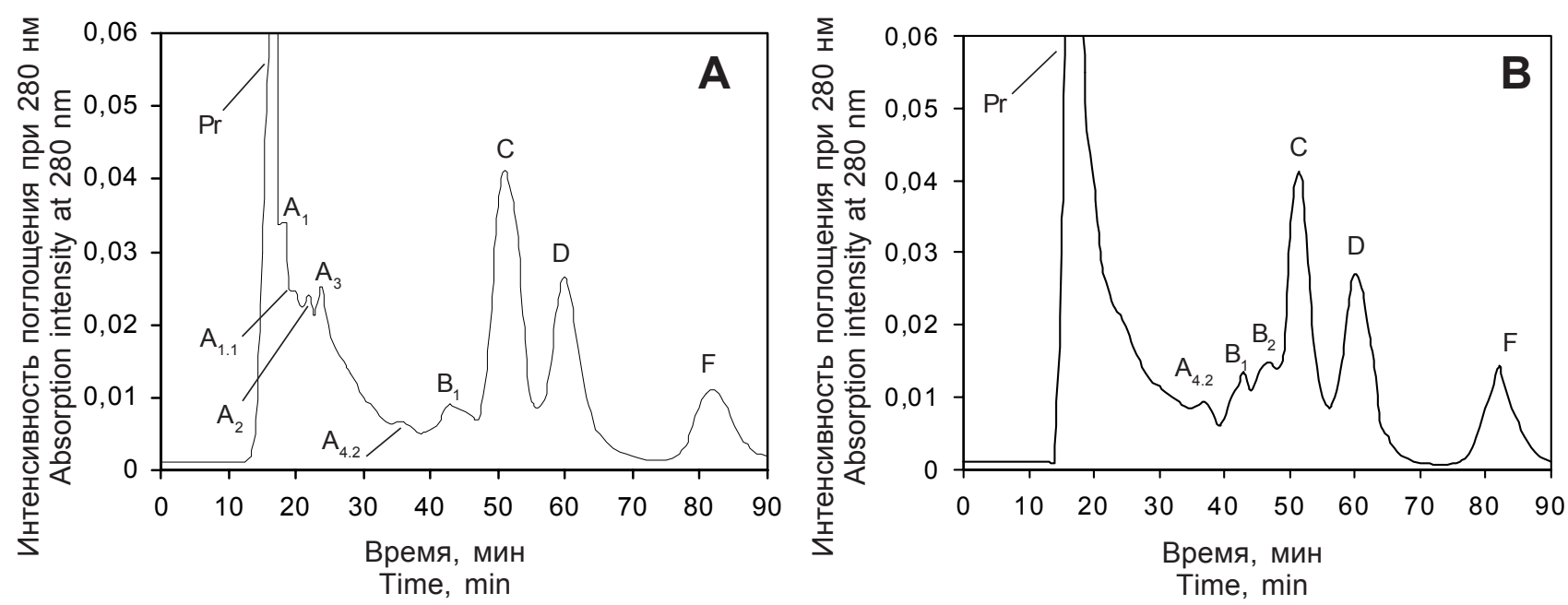

Рис. 1. Типичные хроматограммы распределения белково-пептидных фракций супернатантов из личинок T. molitor: A - неакклимированные; В - акклимированные.

Fig. 1. Typical chromatograms for protein and peptide fractions distribution in supernatants of non-acclimated (A) and acclimated (B) T. molitor larvae.

содержание всех компонентов отличается незначительно. В частности, содержание веществ, которые поглощают в УФ-области спектра, у холодоакклимированных насекомых в 1,11 раза больше, чем у неакклимированных.

Существенно изменялось распределение белково-пептидных компонентов в процессе акклимации. Сравнительный анализ хроматографических данных белково-пептидных фракций из личинок T. molitor показал, что количество белковой фракции (пик Pr) c м. м. $\geq 12000$ Да у неакклимированных личинок в 2,3 раза меньше, чем у холодоакклимированных. У неакклимированных насекомых T. molitor установлено увеличение количества пептидов с низкой м. м.: (2255 \pm 85$)$ Да в $8 ;(1525 \pm 115)$ Да $-2,3$; $(1105 \pm 115)$ Да $-1,3$ и (825 \pm 55) Да - 1,22 раза.

Анализируя полученные данные, можно предположить, что изменение белково-пептидного состава супернатантов, полученых из личинок T. molitor, в процессе низкотемпературной акклимации связано либо с синтезом белково-пептидных компонент de novo, либо со структурными модификациями уже существующих белков.

Обнаруженные качественные и количественные измене- cold-acclimated ones. In non-acclimated T. molitor insects we have found an increase in the number of peptides with low MW: $(2.255 \pm 85)$ Da in $8 ;(1.525 \pm$ 115) $\mathrm{Da}$ in $2.3 ;(1.105 \pm 115) \mathrm{Da}$ in 1.3 , and $(825 \pm 55) \mathrm{Da}$ in 1.22 times.

Analysis of the findings enable to assume that the change in protein-peptide composition of the supernatants derived from T. molitor larvae, during lowtemperature acclimation is associated either with synthesis of protein and peptide components de novo, or structural modifications of existing proteins.

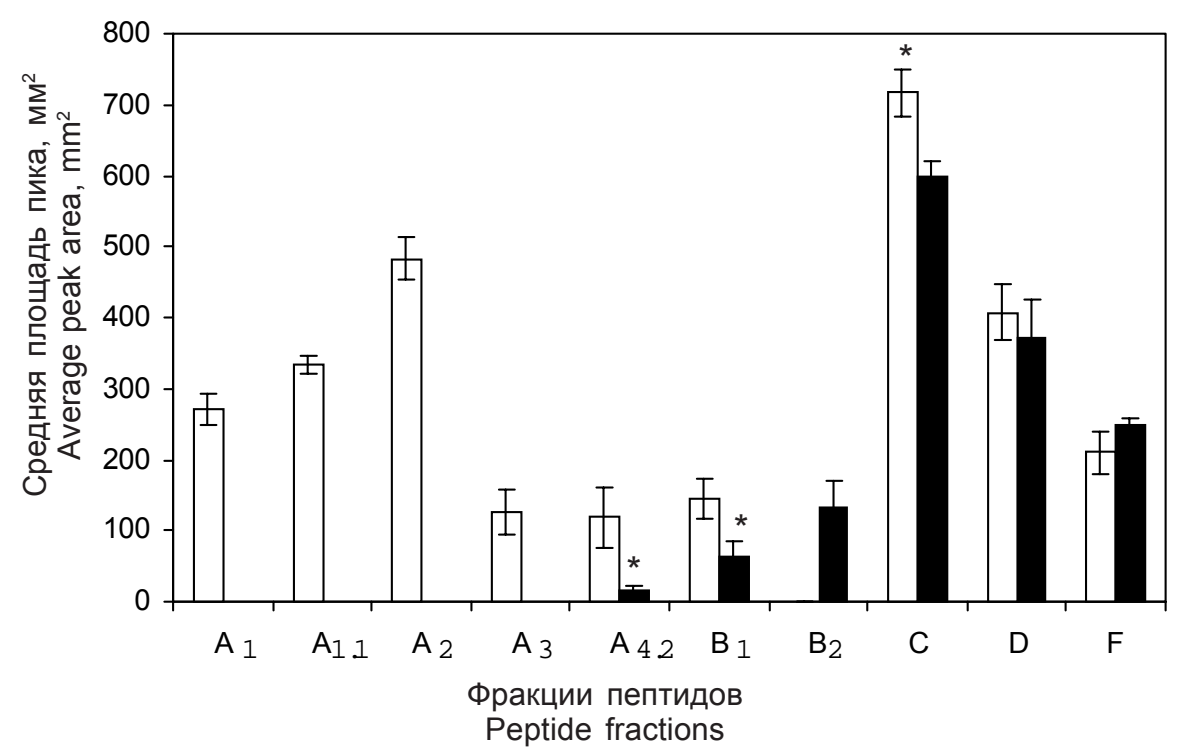

Рис. 2. Молекулярно-массовое распределение пептидных фракций супернатан-

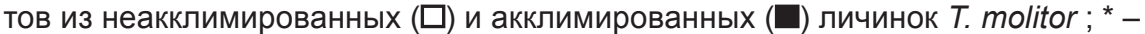
различия значимы по сравнению с неакклимированными личинками, $p<0,05$.

Fig. 2. Molecular weight distribution of peptide fractions in supernatants from non-acclimated $(\square)$ and acclimated $(\square)$ T. molitor larvae; * - differences are significant as compared to non-acclimated larvae, $p<0,05$. 
ния состава белково-пептидных веществ супернатантов из личинок $T$. molitor могут свидетельствовать о наличии молекулярных механизмов адаптации холодоустойчивых личинок T. molitor к действию низких температур, способствующих их выживанию в неблагоприятных условиях среды обитания.

Известно, что в процессе низкотемпературной адаптации холодоустойчивых организмов наблюдаются структурные модификации некоторых белковых молекул, в частности ферментов [6]. Вероятно, что одним из таких изменений является сдвиг по степени гидрофобности, который может быть изучен с помощью метода обращенно-фазовой хроматографии, что позволит определить распределение белков, выделенных из холодоакклимированных и неакклимированных личинок T. molitor (рис. 3).

По времени удерживания белков на колонке, можно установить, что количество гидрофобных белков у неакклимированных личинок T. molitor больше, чем у холодоакклимированных (рис. 3). Белки, которые удерживались на колонке, заполненной гидрофобным веществом, максимальное время являются гидрофобными протеинами, а белки с мини-мальным временем удерживания гидрофильными. У акклимированных насекомых T. molitor выявлено большее количество гидрофильных белков по сравнению с неакклимированными. Результаты экспериментальных исследований согласуются с данными литературы об уменьшении степени гидрофобности белков холодоустойчивых организмов при низкотемпературных адаптациях $[6,16]$.

Известно, что одним из механизмов естественной холодовой адаптации у животных и растений является накопление природных криозащитных веществ (сахаров и сахароспиртов), поэтому с помощью прямофазной высокоэффективной жидкостной хроматографии нами было изучено содержание сахаров и сахароспиртов в супернатантах, полученных из личинок T. molitor (табл. 2).

Как видно из данных табл. 2, у неакклимированных личинок T. molitor уровень глюкозы в 1,34 раза выше, чем у акклимированных. Кроме того, у неакклимированных особей $T$. molitor обнаружены caхароспирты с низкой концентрацией (сорбитол и
The observed qualitative and quantitative changes in the composition of proteins and peptides of the supernatants from $T$. molitor larvae may indicate the presence of molecular mechanisms of adaptation of coldresistant $T$. molitor larvae to low temperatures contributing to their survival under adverse habitat conditions.

It is known that low-temperature adaptation of coldresistant organisms is accompanied with some structural modifications of some protein molecules, $i$. e. enzy-

Таблица 2. Состав супернатантов, полученных из личинок T. molitor

Table 2. Composition of supernatants derived from T. molitor larvae

\begin{tabular}{|c|c|c|}
\hline \multirow[b]{2}{*}{$\begin{array}{l}\text { Вещество } \\
\text { Substance }\end{array}$} & \multicolumn{2}{|c|}{$\begin{array}{l}\text { Концентрация вещества, мг/мл } \\
\text { Substance concentration, } \mathrm{mg} / \mathrm{ml}\end{array}$} \\
\hline & $\begin{array}{c}\text { Неакклимированные } \\
\text { T.molitor } \\
\text { Non-acclimated } \\
\text { T. molitor larvae }\end{array}$ & $\begin{array}{c}\text { Акклимированные } \\
\text { T.molitor } \\
\text { Acclimated T. molitor } \\
\text { larvae }\end{array}$ \\
\hline $\begin{array}{c}\text { Глюкоза } \\
\text { Glucose }\end{array}$ & $2,035 \pm 0,195$ & $1,515 \pm 0,105$ \\
\hline $\begin{array}{l}\text { Фруктоза } \\
\text { Fructose }\end{array}$ & - & - \\
\hline $\begin{array}{c}\text { Сахароза } \\
\text { Sucrose }\end{array}$ & - & - \\
\hline $\begin{array}{l}\text { Лактоза } \\
\text { Lactose }\end{array}$ & - & - \\
\hline $\begin{array}{l}\text { Сорбитол } \\
\text { Sorbitol }\end{array}$ & $0,025 \pm 0,005$ & - \\
\hline $\begin{array}{l}\text { Маннитол } \\
\text { Mannitol }\end{array}$ & $0,020 \pm 0,005$ & - \\
\hline
\end{tabular}


маннитол), которые отсутствуют у акклимированных к холоду насекомых. Изменение углеводного состава в процессе акклимации личинок T. molitor может свидетельствовать о трансформации метаболических процессов образования сахаров и сахароспиртов либо о возможном формировании у насекомых во время акклимации сложных компонентов, например, углеводно-белковых соединений. Это позволяет сохранить и оптимизировать функции протеинов и стабилизировать макромолекулы в условиях стресса.

Анализируя полученные экспериментальные данные, можно предположить, что в механизме сложного и многоэтапного явления холодовой адаптации ключевую роль играют перестройки в метаболизме белков, включая энзимы, белки холодового шока, а также регуляторные белки и пептиды. Для подтверждения данной гипотезы необходимы дополнительные исследования с использованием ингибитора синтеза белков (например, циклогексимида), что является целью последующей экспериментальной работы.

\section{Выводы}

Показано, что во время низкотемпературной адап-тации личинок T. molitor происходят измения спектра белково-пептидных веществ в их тканях: увеличение объема белковой фракции с м. м. 12000 Да, уменьшение объема пептидов с м. м. $(2255 \pm 85)$ и $(1525 \pm 115)$ Да в 8 и 2,3 раза соответственно, а также структурные модификации белков, характеризующиеся снижением их гидрофобности.

Установлено, что в процессе холодовой адаптации личинок T. molitor уменьшается содержание глюкозы, исчезают сахароспирты (сорбитол и маннитол).

\section{Литература}

1. Бидлингмейер Б. Препаративная жидкостная хроматограсия. - М.: Мир, 1990. - 360 с.

2. Гулевский А.К., Рязанцев В.В., Грищенкова Е.А., Релина Л.И. Изменения в спектре белков личинок большого мучного хрущака (Tenebrio molitor) в период холодовой акклимации // Проблемы криобиологии. - 1995. - №4.- С. 29-32.

3. Скоупс Р. Методы очистки белков: Пер. с англ. проф. В.К. Антонова. - М.: Мир, 1985. - 358 с.

4. Bennett V.A., Sformo T., Walters K. et al. Comparative overwintering physiology of Alaska and Indiana populations of the beetle Cucujus clavipes (Fabricius): roles of antifreeze proteins, polyols, dehydration and diapauses // J. Exp. Biol. 2005. - Vol. 208, №23. - P. 446-477.

5. Celik Y., Drori R., Pertaya-Braun N. et al. Microfluidic experiments reveal that antifreeze proteins bound to ice crystals suffice to prevent their growth // PNAS. - 2013. - Vol. 110, №4. P. 1309-1314.

6. D'Amico S., Marx J.C., Gerday C. et al. Activity-stability relationships in extremophilic enzymes // J. Biol. Chem. - 2003. Vol. 278, №10. - P. 7891-7896. mes are observed [4]. One of these changes is likely hydrophobicity degree shift which can be studied using the method of reversed-phase chromatography. It will enable to determine the distribution of proteins derived from cold-acclimated and non-acclimated T. molitor larvae (Fig. 3).

Retention time of proteins in a column allowed to establish, that the amount of hydrophobic proteins in non-acclimated T. molitor larvae was higher than in cold-acclimated ones (Fig. 3). Proteins retained in the column filled with hydrophobic substance during maximum time were hydrophobic proteins and the proteins with a minimal retention time were hydrophilic. A larger amount of hydrophilic proteins in acclimated T. molitor insects compared to non-acclimated ones was revealed. The findings were consistent with the reported data on diminishing the degree of protein hydrophobicity in cold-resistant organisms following low temperature adaptations $[4,15]$.

Accumulation of natural cryoprotective agents (sugars and sugar alcohols) had been known to be one of the mechanisms of cold adaptation in animals and plants, therefore we investigated the content of sugars and sugar alcohols in supernatants, derived from T. molitor larvae using high-performance liquid chromatography (Table 2).

Table 2 demonstrates, that in non-acclimated T.molitor larvae the glucose level is 1.34 times higher than in acclimated ones. Moreover, low concentrations of sugar alcohols (sorbitol and mannite) were observed in non-acclimated T. molitor larvae, and absent in coldacclimated insects. Change in the carbohydrate composition during acclimation of T. molitor larvae may indicate to either transformation of metabolic processes of sugars and sugar alcohols formation or possible formation of complex components such as carbohydrateprotein compounds in insects during acclimation. It allows preservation and optimizations of protein functions, as well as stabilization of macromolecules under stress conditions.

The analysis of experimental data enabled us to assume that in the mechanism of the complex and multistep cold adaptation a key role was played by the rearrangements in protein exchange, including enzymes, cold shock proteins, as well as regulatory proteins and peptides. To confirm this hypothesis there is a need in additional studies using protein synthesis inhibitor (e. g., cycloheximide), which will be the goal of further experiments.

\section{Conclusions}

It has been shown that low-temperature adaptation of T. molitor larvae was accompanied with the changes within spectrum of protein and peptide substances in their tissues occurred. There was an in increase in the amount of protein fractions with MW of $12.000 \mathrm{Da}$, a reduced 
7. Davies P.L., Hew C.L. Biochemistry of fish antifreeze proteins // The FASEB J. - 1990. - Vol. 4, №8. - P. 2460-2468.

8. Duman J.G. Environmental effects on antifreeze levels in larvae of the darkling beetle, Meracantha contracta // J. Exp. Zool. 1977. - Vol. 201, №2. - P. 333-337.

9. Duman J.G. Factors involved in overwintering survival of the freeze tolerant beetle, Dendroides Canadensis // J. Comp. Physiol. - 1980. - Vol. 136, №1. - P. 52-59.

10.Franks F. Protein destabilization at low temperatures // Adv. Prot. Chem. - 1995. - Vol. 46. - P. 105-139.

11.Garnham C.P., Natarajan A., Middleton A.J. et al. Compound ice-binding site of an antifreeze protein revealed by mutagenesis and fluorescent tagging // Biochemistry. - 2010. - Vol. 49, №42. - P. 9063-9071.

12.Gilbert J.A., Hill P.J., Dodd C.E. et al. Demonstration of antifreeze protein activity in Antarctic lake bacteria // Microbiology. 2004. - Vol. 150, №1. - P. 171-180.

13.Graether S.P., Kuiper M.J., Gagne S.M. et al. Beta-helix structure and ice-binding properties of a hyperactive antifreeze protein from an insect // Nature. - 2000. - Vol. 406, №6793. - P. 325328.

14.Graham L.A., Walker V.K., Davies P.L. Developmental and environmental regulation of antifreeze proteins in the mealworm beetle Tenebrio molitor // Eur. J. Biochem. - 2000. - Vol. 267, №21. - P. 6452-6458.

15.Jaenicke R., Bohm G. The stability of proteins in extreme environments // Curr. Opin. Struct. Biol. - 1998. - Vol. 8, №6. P. 738-748.

16.Kahlke T., Thorvaldsen S. Molecular characterization of cold adaptation of membrane proteins in the Vibrionaceae coregenome // PLOS One. - 2012. - Vol. 7, №12. - e51761.

17.Liou Y.C., Thibault P., Walker V.K. et al. A complex family of highly heterogeneous and internally repetitive hyperactive antifreeze proteins from the beetle Tenebrio molitor // Biochemistry. - 1999. - Vol. 38, №35. - P. 11415-11424.

18.Patterson J.L., Duman J.G. Purification and composition of protein antifreezes with high cysteine contents from larvae of the beetle, Tenebrio molitor // J. Exp. Zool. - 1982. - Vol. 219, №3. - P. 381-384.

19.Posner M. Functional validation of hydrophobic adaptation to physiological temperature in the small heat shock protein $\alpha \mathrm{A}$ crystallin // PLOS One. - 2012. - Vol. 7, №3. - e34438.

20.Singh P., Hanada Y., Singh S.M. et al. Antifreeze protein activity in Arctic cryoconite bacteria // FEMS Microbiol. Lett. - 2014. Vol. 351, №1. - P. 14-22.

21.Wohrmann A.P.A. Antifreeze glycopeptides and peptides in Antarctic fish species from the Weddell Sea and the Lazarev Sea // Mar. Ecol. Prog. Ser. - 1996. - Vol. 130. - P. 47-59. volume of peptides with MW $(2,255 \pm 85)$ and $(1,525 \pm$ $115)$ Da by 8 and 2.3 times, respectively, structural modifications of proteins, characterized by the decrease in their hydrophobicity as well.

It has been found that during cold adaptation of T. molitor larvae the glucose content was decreased, and the sugar alcohols (sorbitol and mannite) disappeared.

\section{References}

1. Bennett V.A., Sformo T., Walters K. et al. Comparative overwintering physiology of Alaska and Indiana populations of the beetle Cucujus clavipes (Fabricius): roles of antifreeze proteins, polyols, dehydration and diapauses. J Exp Biol 2005; 208(23): 4467-4477.

2. Bidlingmayer B. Preparative liquid chromatography. Moscow: Mir, 1990.

3. Celik Y., Drori R., Pertaya-Braun N. et al. Microfluidic experiments reveal that antifreeze proteins bound to ice crystals suffice to prevent their growth. PNAS 2013; 110(4): 1309-1314.

4. D'Amico S., Marx J.C., Gerday C. et al. Activity-stability relationships in extremophilic enzymes. J Biol Chem 2003; 278(10): 7891-7896.

5. Davies P.L., Hew C.L. Biochemistry of fish antifreeze proteins. FASEB J. 1990; 4(8): 2460-2468.

6. Duman J.G. Environmental effects on antifreeze levels in larvae of the darkling beetle, Meracantha contracta. J Exp Zool 1977; 201(2): 333-337.

7. Duman J.G. Factors involved in overwintering survival of the freeze tolerant beetle, Dendroides Canadensis. J Comp Physiol 1980; 136(1): 52-59.

8. Franks F. Protein destabilization at low temperatures. Adv Prot Chem 1995; 46: 105-139.

9. Garnham C.P., Natarajan A., Middleton A.J. et al. Compound icebinding site of an antifreeze protein revealed by mutagenesis and fluorescent tagging. Biochemistry 2010; 49(42): 9063-9071.

10.Gilbert J.A., Hill P.J., Dodd C.E. et al. Demonstration of antifreeze protein activity in Antarctic lake bacteria. Microbiology 2004; 150(1): 171-180.

11.Graether S.P., Kuiper M.J., Gagne S.M. et al. Beta-helix structure and ice-binding properties of a hyperactive antifreeze protein from an insect. Nature 2000; 406(6793): 325-328.

12.Graham L.A., Walker V.K., Davies P.L. Developmental and environmental regulation of antifreeze proteins in the mealworm beetle Tenebrio molitor. Eur J Biochem 2000; 267(21): 6452-6458.

13.Gulevsky A.K., Ryazantsev V.V., Grischenkova Ye.A., Relina L.I. Changes in protein composition of mealworms (Tenebrio molitor) during cold acclimation. Problems of Cryobiology 1995; (4): 29-32.

14.Jaenicke R., Bohm G. The stability of proteins in extreme environments. Curr Opin Struct Biol 1998; 8(6): 738-748.

15. Kahlke T., Thorvaldsen S. Molecular characterization of cold adaptation of membrane proteins in the Vibrionaceae coregenome. PLOS One 2012; 7(12): e51761.

16.Liou Y.C., Thibault P., Walker V.K. et al. A complex family of highly heterogeneous and internally repetitive hyperactive antifreeze proteins from the beetle Tenebrio molitor. Biochemistry 1999; 38(35): 11415-11424.

17.Patterson J.L., Duman J.G. Purification and composition of protein antifreezes with high cysteine contents from larvae of the beetle, Tenebrio molitor. J Exp Zool 1982; 219(3): 381-384.

18.Posner M. Functional validation of hydrophobic adaptation to physiological temperature in the small heat shock protein $\alpha \mathrm{A}$-crystallin. PLOS One 2012; 7(3): e34438.

19.Scopes R. Methods of protein purification. Moscow: Mir; 1985.

20.Singh P., Hanada Y., Singh S.M. et al. Antifreeze protein activity in Arctic cryoconite bacteria. FEMS Microbiol Lett 2014; 351(1): 14-22.

21. Wohrmann A.P.A. Antifreeze glycopeptides and peptides in Antarctic fish species from the Weddell Sea and the Lazarev Sea. Mar Ecol Prog Ser 1996; 130: 47-59. 